\title{
Total numbers matter. Landscape of China's scientific publications in 2018-2020 on the energy issue
}

\author{
B.N. Chigarev \\ Oil and Gas Research Institute, Russian Academy of Sciences, Moscow \\ E-mail: bchigarev@ipng.ru
}

Abstract. This study aims to reveal and analyze the landscape of China's scientific publications in 2018-2020 on the subject "Energy Engineering and Power Technology" using bibliometric data from the Lens platform.

Bibliometric data of 26,623 scholarly works that satisfy the query: "Filters: Year Published = (2018-); Publication Type $=$ (journal article); Subject $=$ (Energy Engineering and Power Technology); Institution Country/Region = $(\text { China })^{\prime \prime}$ were used to analyze their main topics disclosed by Fields of Study and Subject; the leading contributors to these R\&D activities were also detected.

Chinese Academy of Sciences, China University of Petroleum, Tsinghua University, Xi'an Jiaotong University, China University of Mining and Technology are the leading institutions in the subject. Most research works were funded by National Natural Science Foundation of China.

China carries out its research not only in conjunction with the leading economies: United States, United Kingdom, Australia and Canada, but also with the developing countries: Pakistan, Iran, Saudi Arabia and Viet Nam. Materials science, Chemical engineering, Computer science, Chemistry, Catalysis, Environmental science are the top Fields of Study.

Analysis of co-occurrence of Fields of Study allowed to identify 5 thematic clusters: 1 . Thermal efficiency and environmental science; 2 . Materials science for energy storage and hydrogen production; 3. Catalysis and pyrolysis for better fossil fuels; 4 . Computer science and control theory for renewable energy; 5 . Petroleum engineering for new fossil fuel resources and composite materials.

The results of the work can serve as a reference material for scientists, developers and investors, so that they can understand the research landscape of the "Energy Engineering and Power Technology" subject.

Keywords: China, energy engineering and power technology, landscape of publications, bibliometrics, the Lens, field of study.

Citation: Chigarev B.N. Total numbers matter. Landscape of China's scientific publications in 2018-2020 on the energy issue // Actual Problems of Oil and Gas. 2021. Iss. 1(32). P. 76-101. https://doi.org/10.29222/ipng.2078-5712.2021-32.art7

\section{Introduction}

Research and development (R\&D) is expensive but plays an important role in improving competitiveness. Researchers, technology innovators and decision-makers need to understand the structure of global trends, therefore, the analysis of scholarly works carried out by the world's leading economies is becoming an essential component in developing effective decisions on science funding.

The bibliometric analysis contributes significantly to understanding the landscape of academic publications and the hot topics of R\&D [1]. In recent decades, China has become one of the leading nations in science and $\mathrm{R} \& \mathrm{D}[2]$. 
Chinese authors make extensive use of bibliometric analysis to construct research profiles, study global scientific cooperation and identify trends in the development of specific areas of knowledge [3-6]. In the main they use data from Scopus, Web of Science and Chemical Abstracts Service, but the Lens platform has additional features: classification by subjects of research, fields of study, open access to its resources and wider indexing coverage. In this study, "Energy Engineering and Power Technology", the main subject category of Energy subject area as classified by Elsevier*, was biometrically analyzed.

General note: in this article, the terms used by the Lens platform are given in their original form, for example, Field of Study, Subject, Energy Engineering and Power Technology, Materials Science, in order to separate them from the rest of the text.

\section{Materials and methods}

\subsection{Data}

"Energy Engineering and Power Technology" subject includes 560,318 scholarly works in the Lens database. In 2018-2020，90,173 documents were published: 26,366 by China, 10,393 by United States and 4,319 by India. Considering only journal articles, we get the final request to the Lens: "Filters: Year Published $=(2018-) ;$ Publication Type $=($ journal article $) ;$ Subject $=($ Energy Engineering and Power Technology); Institution Country/Region = (China)", which gives 26,623 scholarly works as the result for further analysis.

\subsection{Methods}

Scholar analysis by the Lens platform provides a flexible possibility to build data slices. We use it to get top institution name, top funding, countries, subjects, fields of study and so on.

For each top item, 3 or 4 highly cited articles with their brief analysis were proposed as examples. Moreover, we use VOSviewer, a software tool for constructing and visualizing bibliometric networks [7], to cluster Field of Study data based on their co-occurrence.

Fields of study are used by the Microsoft Academic Graph (MAG) and exposed as Topics on the Microsoft Academic website to categorize entities. They are defined by machine learning parsing of all accessible text in bibliometric records. The Lens is based on Microsoft Academic Index and includes currently $225,109,652$ scholarly works.

\section{Results}

During the last 10 years, the number of Chinese publications on "Energy Engineering and Power Technology" subject more than doubled compared to the global average: 2,041 articles in 2011 and 10,375 in 2020 (as of 12.06.2020) compared to 15,004 articles in 2011 and 34,173 in 2020 published by all countries (Fig. 1).

Journal articles are the main type of publications. Book chapters and conference proceedings are minor. Chinese authors strive to have their articles indexed in leading international abstract databases.

\footnotetext{
*https://www.scimagojr.com/journalrank.php?area=2100\&category=2102
} 


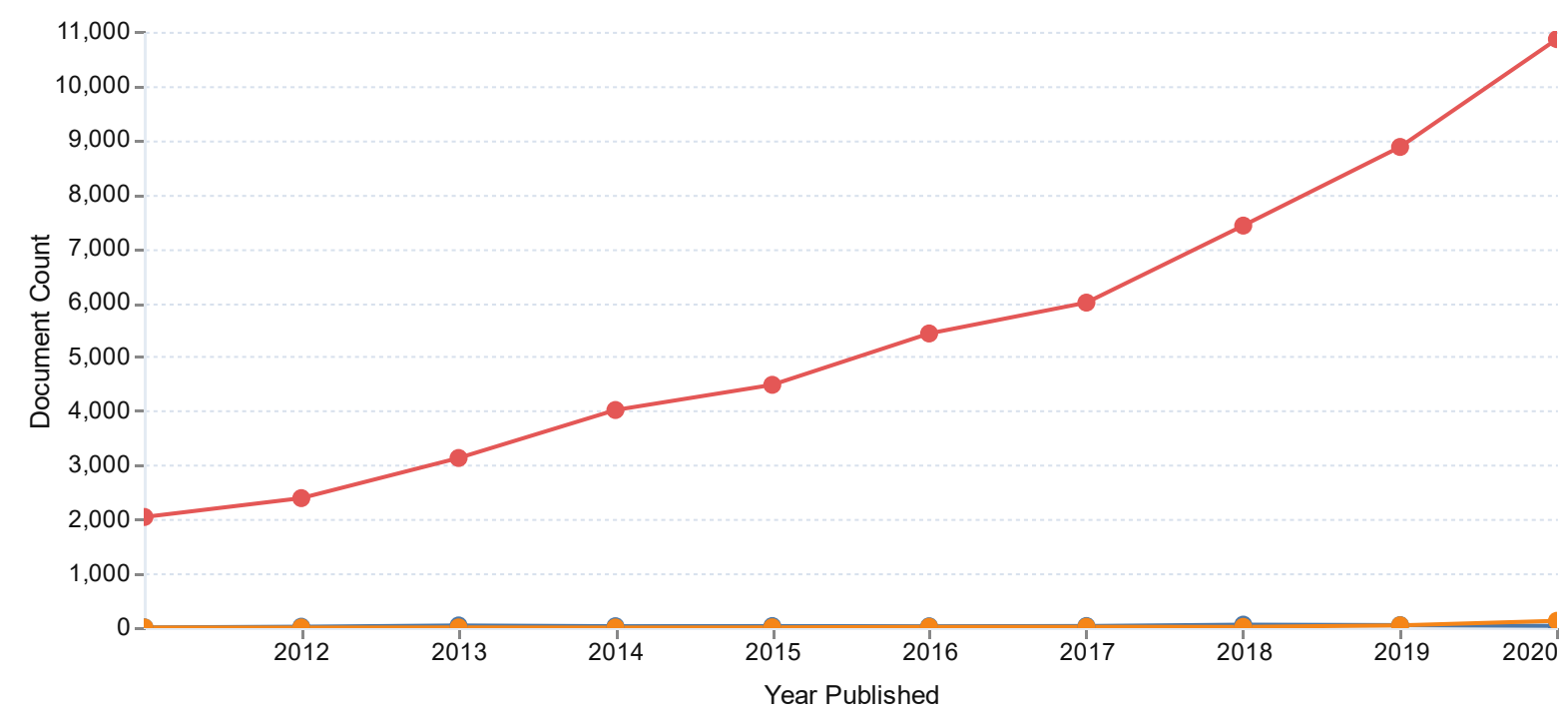

Publication Type

Book Chapter Conference Proceedings Journal Article

Fig. 1. The number of scholarly works over time by their publication type

\subsection{Top Institution Name by} Document Count on "Energy Engineering and Power Technology" subject for 2018-2020

Chinese organizations lead the overall list (without "China" filter) of publication activity (Fig. 2).

Examples of top cited articles by Chinese Academy of Sciences [8-10] and their Field of Study \{Electrochemistry $\rightarrow 2$; Ion $\rightarrow 2$; Lithium $\rightarrow 2$; Materials science $\rightarrow 2$; Anode $\rightarrow 1$; $\quad$ Battery $\quad$ (electricity) $\rightarrow 1$; Capacitance $\rightarrow 1$ ， Carbon $\rightarrow 1$ ， Cathode $\rightarrow 1$;
Chemical engineering $\rightarrow 1$; Energy storage $\rightarrow 1$; Environmental science $\rightarrow 1$; Heavy metals $\rightarrow 1$; Human health $\rightarrow 1$; Hydrometallurgy $\rightarrow 1$; Inorganic chemistry $\rightarrow 1$; Mesoporous material $\rightarrow 1$; $\quad$ Metal recycling $\rightarrow 1$; Mini review $\rightarrow 1$; Nanocrystal $\rightarrow 1$; Polymerization $\rightarrow 1$; Pyrometallurgy $\rightarrow 1$; $\quad$ Sodium $\rightarrow 1$; Supercapacitor $\rightarrow 1$; Waste management $\rightarrow 1$ \} . Hence, we can assume that Materials science for Supercapacitor and Battery, including impact of Heavy metals on Human health, are the main topics of those researches.

\begin{tabular}{|c|c|c|c|c|}
\hline $\begin{array}{l}1,259 \\
\text { China University of Mining } \\
\text { and Technology }\end{array}$ & $\begin{array}{l}1,548 \\
\text { China University of } \\
\text { Petroleum }\end{array}$ & $\begin{array}{l}2,212 \\
\text { Chinese Academy of Sciences }\end{array}$ & $\begin{array}{l}993 \\
\text { Huazhong University of } \\
\text { Science and Technology }\end{array}$ & $\begin{array}{l}804 \\
\text { Russian Academy of Scienc }\end{array}$ \\
\hline $\begin{array}{l}975 \\
\text { Shanghai Jiao Tong } \\
\text { University }\end{array}$ & $\begin{array}{l}900 \\
\text { Tianjin University }\end{array}$ & $\begin{array}{l}1,398 \\
\text { Tsinghua University }\end{array}$ & $\begin{array}{l}1,378 \\
X i^{\prime} \text { an Jiaotong University }\end{array}$ & $\begin{array}{l}838 \\
\text { Zhejiang University }\end{array}$ \\
\hline
\end{tabular}

Fig. 2. Top institutions, based on their number of scholarly works in the result for the query:

"Filters: Year Published $=(2018-)$;

Publication Type = (journal article);

Subject $=$ (Energy Engineering and Power Technology $)^{\prime \prime}$ 
Examples of top cited articles by China University of Petroleum [11-13] and their Field of Study \{Geothermal energy $\rightarrow 2$; Geothermal gradient $\rightarrow 2$; Mass flow rate $\rightarrow 2$; Petroleum engineering $\rightarrow 2$; Working fluid $\rightarrow 2$; Carbonate $\rightarrow 1$; Closed loop $\rightarrow 1$; Environmental science $\rightarrow 1$; $\quad$ Fossil $\quad$ fuel $\rightarrow 1$; $\quad$ Geology $\rightarrow 1$; Injection $\quad$ rate $\rightarrow 1$; Macropore $\rightarrow 1$; Mass flow $\rightarrow 1$; $\quad$ Mass $\quad$ transfer $\rightarrow 1$; $\quad$ Materials science $\rightarrow 1 ; \quad$ Mineralogy $\rightarrow 1$; Oil $\quad$ shale $\rightarrow 1$; Organic geochemistry $\rightarrow 1$; Porosity $\rightarrow 1$; Pressure drop $\rightarrow 1$; $\quad$ Quartz $\rightarrow 1$; $\quad$ Scanning electron microscope $\rightarrow 1$; Total organic carbon $\rightarrow 1\}$. So, Oil shale, Geothermal energy, Environmental science are in focus of China Petroleum sector.

\subsection{Top Countries by Document Count on "Energy Engineering and Power Technology" subject for 2018-2020}

China publishes 2.57 times more articles than the United States. It is worth noting that Iran publishes more articles on the topic than India or the United Kingdom (Fig. 3.).

\begin{tabular}{|c|c|c|c|c|}
\hline 2,318 & 2,649 & 27,565 & 2,165 & 4,230 \\
\hline Australia & Canada & China & Germany & India \\
\hline 4,239 & 2,134 & 2,223 & 3,657 & 10,735 \\
\hline Iran & Japan & Korea, Republic of & United Kingdom & United States \\
\hline
\end{tabular}

Fig. 3. Top institutions by their number of scholarly works

China carries out its research not only in conjunction with the leading economies \{United States $\rightarrow 2,812$ shared publications; United Kingdom $\rightarrow$ 934; Australia $\rightarrow$; 16 ; Canada $\rightarrow 585\}$, but also with developing countries $\quad$ \{Pakistan $\rightarrow 156$; Iran $\rightarrow 120$; Saudi Arabia $\rightarrow 111$; $\quad$ Viet $\quad \mathrm{Nam} \rightarrow 103 \quad$ shared publications $\}$.

Remark: since we used "China" as a filter in collecting bibliometric data, the mention of other countries in the results obtained will be associated with the presence of non-Chinese coauthors in the publications.

\subsection{Top Funding by Document Count with "China" as a filter}

Format of the list: Funding $\rightarrow$ Document Count.

- National Natural Science Foundation of China $\rightarrow 15,299$

- Fundamental Research Funds for the Central Universities $\rightarrow 2,097$
- National Basic Research Program of China (973 Program) $\rightarrow 1,454$

- China Postdoctoral Science Foundation $\rightarrow 1,265$

- National Key R\&D Program of China $\rightarrow 773$

- China Scholarship Council $\rightarrow 662$

- Ministry of Science and Technology of the People's Republic of China $\rightarrow 565$

- Natural Science Foundation of Shandong Province $\rightarrow 465$

- Natural Science Foundation of Jiangsu Province $\rightarrow 462$

- National Key Research and Development Program of China $\rightarrow 429$

- Chinese Academy of Sciences $\rightarrow 384$

- Ministry of Education of the People's Republic of China $\rightarrow 328$

- Natural Science Foundation of Guangdong Province $\rightarrow 311$ 
- Natural Science Foundation of Beijing Municipality $\rightarrow 205$

- Priority Academic Program Development of Jiangsu Higher Education Institutions $\rightarrow 196$

- National Science Foundation $\rightarrow 179$

- Natural Science Foundation of Zhejiang Province $\rightarrow 172$

- National Key Research and Development Program of China Stem Cell and Translational Research $\rightarrow 153$

National Natural Science Foundation of China is the main sponsor of all research projects in China, but along with this, there is a broad diversification of funding for science, including foreign funds, for example, National Science Foundation (USA).

Examples of top cited articles funded by National Natural Science Foundation of China [14-16] and their Field of Study: \{Battery (electricity) $\rightarrow 2$; $\quad$ Energy $\quad$ density $\rightarrow 2$; Lithium $\rightarrow 2$; Lithium-ion battery $\rightarrow 2$; Materials science $\rightarrow 2$; Acoustics $\rightarrow 1$; All solid state $\rightarrow 1$; Chemical engineering $\rightarrow 1$; Computational fluid dynamics $\rightarrow 1$; Electric vehicle $\rightarrow 1$; Electrical engineering $\rightarrow 1$; Electrolyte $\rightarrow 1$; Energy harvesting $\rightarrow 1$; Fast ion conductor $\rightarrow 1$; Ion $\rightarrow 1$; Nuclear $\quad$ engineering $\rightarrow 1$; $\quad$ Physics $\rightarrow 1$; Piezoelectricity $\rightarrow 1$; $\quad$ Short $\quad$ circuit $\rightarrow 1$; Thermal $\rightarrow 1$; $\quad$ Thermal $\quad$ runaway $\rightarrow 1$; Vibration $\rightarrow 1$; Vortex $\rightarrow 1$; Vortex-induced vibration $\rightarrow 1$; Wind $\quad$ power $\rightarrow 1$; Wind tunnel $\rightarrow 1$ \}.

This list implies that not only Materials science and Battery, but also Nuclear engineering, Chemical engineering and even such non-ordinary research area as Energy harvesting by Wind power are in focus of China's funding organizations.

If we took in consideration the National Science Foundation (USA), we get the following examples of top cited articles [17-19] and their
Field of Study \{Materials science $\rightarrow$ 3; Anode $\rightarrow 1$; $\quad$ Battery (electricity) $\rightarrow 1$; Capacitance $\rightarrow 1$; Cathode $\rightarrow 1$; Chemical kinetics $\rightarrow 1$; Combustion $\rightarrow 1$; Doping $\rightarrow 1$; Double bond $\rightarrow 1$; Electrode $\rightarrow 1$; Electrolyte $\rightarrow 1$; Flame speed $\rightarrow 1$; $\quad$ Graphene $\rightarrow 1$; Inorganic chemistry $\rightarrow 1$; Laminar flame $\quad$ speed $\rightarrow 1$; Lithium $\rightarrow 1$; Lithium vanadium phosphate battery $\rightarrow 1$; Molecule $\rightarrow 1$; Nanoarchitectures for lithium-ion batteries $\rightarrow 1$; Nanotechnology $\rightarrow 1$; Optoelectronics $\rightarrow 1$; $\quad$ Pentoxide $\rightarrow 1$; $\quad$ Power density $\rightarrow 1$; $\quad$ Radical $\rightarrow 1$; $\quad$ Supercapacitor $\rightarrow 1$; Thermochemistry $\rightarrow 1$; $\quad$ Thermodynamics $\rightarrow 1$; Vanadium $\rightarrow 1$; Voltage $\rightarrow 1\}$. If the first article concerns the in-depth experimental studies on Combustion, Chemical kinetics and Laminar flame speed, the two others relate to Supercapacitor, Nanotechnology, Materials science and Battery.

\subsection{Top Fields of Study by Document Count of China's publication activity on "Energy Engineering and Power Technology" subject}

Format of the list: Field of Study $\rightarrow$ Document Count.

- Materials science $\rightarrow 14,489$

- Chemical engineering $\rightarrow 6,961$

- Computer science $\rightarrow 3,492$

- Chemistry $\rightarrow 3,180$

- Catalysis $\rightarrow 2,784$

- Environmental science $\rightarrow 2,726$

- Mechanics $\rightarrow 2,579$

- Combustion $\rightarrow 1,864$

- Coal $\rightarrow 1,661$

- Electrochemistry $\rightarrow 1,629$

- Control theory $\rightarrow 1,515$

- Composite material $\rightarrow 1,437$

- Hydrogen $\rightarrow 1,391$

- Anode $\rightarrow 1,338$

- Carbon $\rightarrow 1,318$

- Electrolyte $\rightarrow 1,251$ 
- Geology $\rightarrow 1,216$

- Electrode $\rightarrow 1,192$

- Adsorption $\rightarrow 1,179$

- Heat transfer $\rightarrow 1,168$

China's publication activity is comparable with the overall performance: Materials science $\rightarrow 33,807$; Computer science $\rightarrow 15,257$; Chemical engineering $\rightarrow 14,244$; Environmental science $\rightarrow 10,806$; Chemistry $\rightarrow 7,797$.

Examples of top cited articles on Field of Study (Materials science): [20-23] and the list of Fields of Study of this articles: \{Materials science $\rightarrow 4$; Chemical engineering $\rightarrow 3$; Electrochemistry $\rightarrow 3$; Specific surface area $\rightarrow 3$; Anode $\rightarrow 2 ; \quad$ Adsorption $\rightarrow 1$; Annealing (metallurgy) $\rightarrow 1$; Carbon nanofiber $\rightarrow 1$; Coal $\rightarrow 1$; Composite number $\rightarrow 1$; Desorption $\rightarrow 1$; Electrochemical reduction of carbon dioxide $\rightarrow 1$; Electrolyte $\rightarrow 1$; Electrospinning $\rightarrow 1$; Graphene $\rightarrow 1$; Hybrid material $\rightarrow 1$; Ionic liquid $\rightarrow 1$; Lithium $\rightarrow 1$; Metal $\rightarrow 1$; Metal-organic framework $\rightarrow 1$; Nanofiber $\rightarrow 1$; Nanoparticle $\rightarrow 1$; Nanotechnology $\rightarrow 1$; Oxide $\rightarrow 1$; $\quad$ Porosity $\rightarrow 1$; Rational design $\rightarrow 1$; Surface roughness $\rightarrow 1$; Water block $\rightarrow 1$; Water treatment $\rightarrow 1$ \} .

Main highlights of these articles (3 for each):

- High-performance energy storage devices for applications ranging from portable electronics to electric vehicles stimulate research on new-type batteries beyond lithium-ion batteries.

- $\mathrm{Fe}_{7} \mathrm{Se}_{8} / \mathrm{N}-\mathrm{CNF}$ hybrid material has been fabricated, which combines the advantages of interconnected N-rich carbon nanofibers and ultrasmall $\mathrm{Fe}_{7} \mathrm{Se}_{8}$ nanoparticles.

- The hybrid materials based on metal selenides open the way for the development of advanced energy storage systems.

- Environmental problem associated with the use of fuel could be solved by chemical conversion, which reduces $\mathrm{CO}_{2}$ emission.
- Pristine MOFs materials used as the electrocatalysts for $\mathrm{CO}_{2}$ reduction exhibit excellent electrocatalytic activity and selectivity.

- MOF-derived materials improve electron transfer and mass transport.

- Two-dimensional layered vanadium disulfide $\left(\mathrm{VS}_{2}\right)$ is a promising anode material for lithium-ion batteries (LIBs) due to the high theoretical capacity, but it remains a challenge to synthesize monodispersed ultrathin $\mathrm{VS}_{2}$ nanosheets.

- A novel solvothermal method has been developed to prepare the monodispersed bowlshaped $\mathrm{NH}_{3}$-inserted $\mathrm{VS}_{2}$ nanosheets.

- An anode material for LIBs, porous monodispersed $\mathrm{VS}_{2}\left(\mathrm{H}-\mathrm{VS}_{2}\right)$, delivers superior rate performance and longer cycle stability.

- The large-scale coal resources and the increasing demand for clean energy enforce the exploitation of unconventional gas reservoirs such as coalbed methane (CBM).

- It is of great significance to understand how to change the pore structure of coal for CBM mining.

- Ionic liquids can reduce the damage of water block effect and widen the pore diameter.

\subsection{Top Fields of Study by Average Scholar Citations}

If we consider articles related to the most cited Fields of Study, then we get the following picture of more specific terms in comparison with the top Fields of Study by number of publications (format: Field of Study $\rightarrow$ Average Scholar Citations): Energy density $\rightarrow 19.8$; Fast ion conductor $\rightarrow 16.4$; Lithium-sulfur battery $\rightarrow 15.1$; Deep learning $\rightarrow 14.9$; Nanotechnology $\rightarrow 14.7$; Engineering physics $\rightarrow 14.6$; Dendrite (crystal) $\rightarrow 14.5$; $\quad$ Electricity $\quad$ market $\rightarrow 14.0$; Chemical vapor deposition $\rightarrow 14.0$; Lithium-ion battery $\rightarrow 13.7$; Battery pack $\rightarrow 13.7$; Electronics $\rightarrow 13.7$; Polysulfide $\rightarrow 13.3$; Sodium-ion battery $\rightarrow 13.3$; Capacity loss $\rightarrow 13.2$. 
Examples of top cited articles on the most cited Field of Study (Energy density OR Fast ion conductor) [24-27] and the Fields of Study of this articles: \{Fast ion conductor $\rightarrow 4$; Materials science $\rightarrow 4$; $\quad$ Chemical engineering $\rightarrow 3$; Electrode $\rightarrow 3$; Electrolyte $\rightarrow 3$; Ionic conductivity $\rightarrow 2$; $\quad$ Activation $\quad$ energy $\rightarrow 1$; Anode $\rightarrow 1$; $\quad$ Band $\quad$ gap $\rightarrow 1$; $\quad$ Battery (electricity) $\rightarrow 1$; Carbon nanofiber $\rightarrow 1$; Cathode $\rightarrow 1$; Chemical physics $\rightarrow 1$; Composite number $\rightarrow 1$; Conductivity $\rightarrow 1$; $\quad$ Crystal structure $\rightarrow 1$; Density functional theory $\rightarrow 1$; Doping $\rightarrow 1$; $\quad$ Electrochemistry $\rightarrow 1$; Electrospinning $\rightarrow 1 ; \quad$ Ion $\rightarrow 1 ; \quad$ Lithium $\rightarrow 1$; Nanofiber $\rightarrow 1 ; \quad$ Nanoparticle $\rightarrow 1 ; \quad$ Oxide $\rightarrow 1$; Statistical analysis $\rightarrow 1$; Sulfide $\rightarrow 1\}$.

Main highlights for those articles (3 for each):

- Conductivities of the sulfides are the most important property for the electrolytes, which is closely related to their crystal structures.

- Lithium-ion conductivity can be improved by various doping methods, such as substitution doping, interstitial doping, dual-doping, etc.

- Cost-effective silicon was employed to replace the costly germanium in tetragonal $\mathrm{Li}_{10} \mathrm{GeP}_{2} \mathrm{~S}_{12}$-type electrolytes.

- The as-assembled SIC full device exhibits an ultrahigh energy density of 182.8 $\mathrm{Wh} / \mathrm{kg}$. The SIC device was assembled with CNF@NVPF as the cathode and pCNF as the anode.

- The interconnected carbon fiber network provides strong mechanical robustness.

- Carbon nanofiber NVPF particles are completely encapsulated into carbon matrix of CNF.

- $\mathrm{Na}_{11} \mathrm{Ge}_{2} \mathrm{PS}_{12}$ is a promising candidate as a solid $\mathrm{Na}$ electrolyte due to its high room temperature ionic conductivity and phase stability.
- $\mathrm{Na}_{11} \mathrm{Sn}_{2} \mathrm{PS}_{12}$ has been reported to have a room temperature ionic conductivity of 1.4 $\mathrm{mS} / \mathrm{cm}$.

- Substituting $\mathrm{Sn}$ with Ge increases the band gap, improves the room temperature conductivity by a factor of 2 , and lowers the activation energy of $\mathrm{Na}$ hopping.

- $\mathrm{PEO}-\mathrm{NaClO}_{4}$ filled in the space between $\mathrm{Na}_{3} \mathrm{PS}_{4}$ particles, the interfacial resistance of solid electrolyte could be reduced, increasing the ionic conductivity of composite electrolyte.

- With a higher ionic Conductivity and better interfacial compatibility of the NPS-PEO electrolyte, the $\mathrm{SnS}_{2} / \mathrm{Na}$ battery delivers improved cycling stability.

- The all-solid-state battery $\mathrm{SnS}_{2} / \mathrm{Na}$ shows enhanced electrochemical performance.

In addition, Fields of Study can be listed, which in total are most often cited by patents (format: Field of Study $\rightarrow$ Sum by Patent Citations): \{Materials $\quad$ science $\rightarrow 126$; $\quad$ Chemical engineering $\rightarrow 74$; $\quad$ Computer $\quad$ science $\rightarrow$ 45; Electrolyte $\rightarrow 24$; Control theory $\rightarrow 21$; Anode $\rightarrow 21$; $\quad$ Battery (electricity) $\rightarrow 21$; Lithium $\rightarrow 20$, the common landscape is the same: exploration on Materials science, Chemical engineering and Computer science for efficient electricity Battery.

\subsection{Top Institution Name by Field of Study and by Subject compared by Document Count}

Fig. 4 and Fig. 5 show the leading scientific organizations with the highest number of publications in the Fields of Study and Subjects categories, respectively.

The Chinese Academy of Sciences is the leading institution in most Fields of Study, with the exception of Computer Science, which is dominated by Tsinghua University, North China Electric Power University and Electric Power Research Institute. 


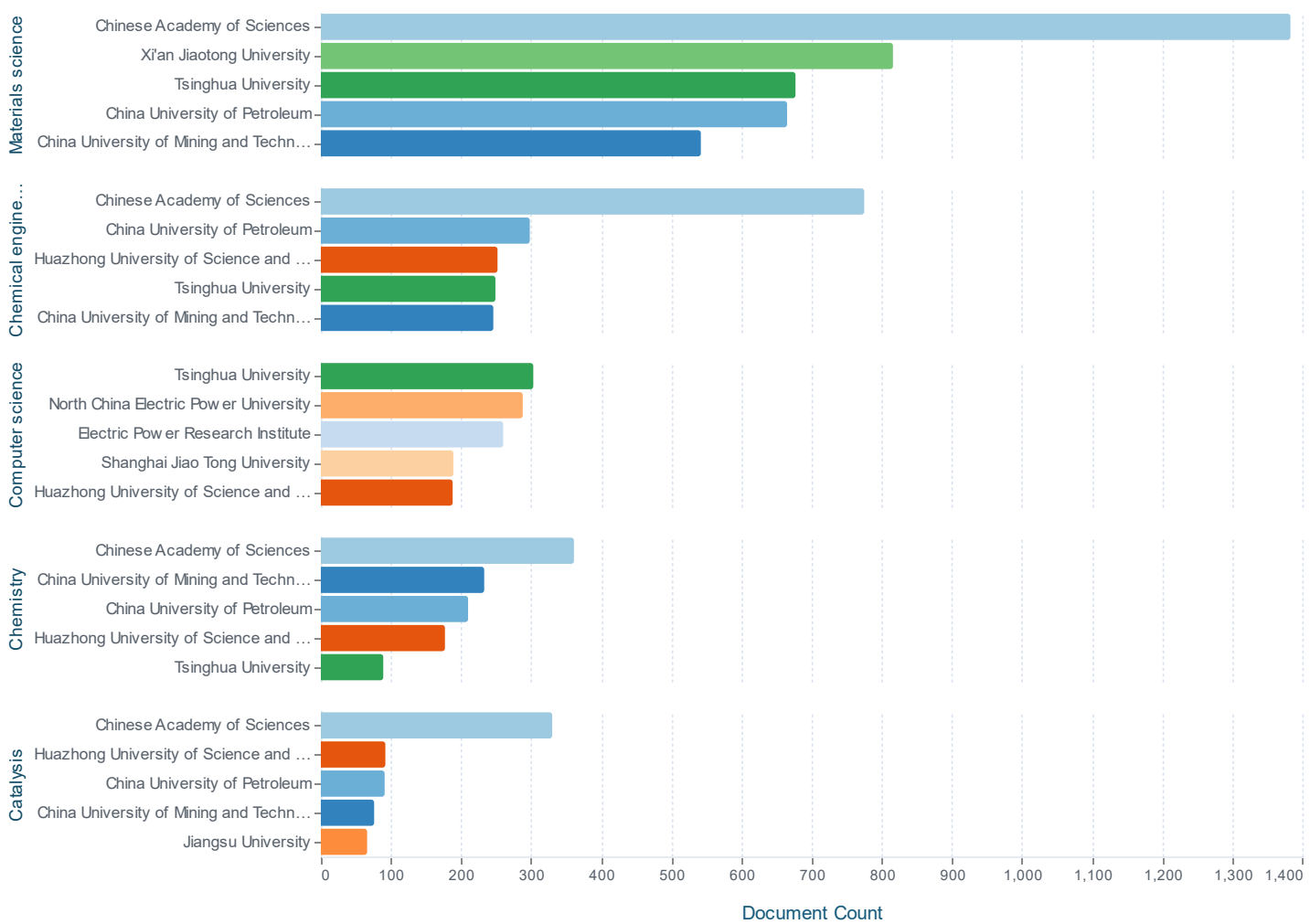

Fig. 4. The main Fields of Study for the most active institutions, based on their number of scholarly works

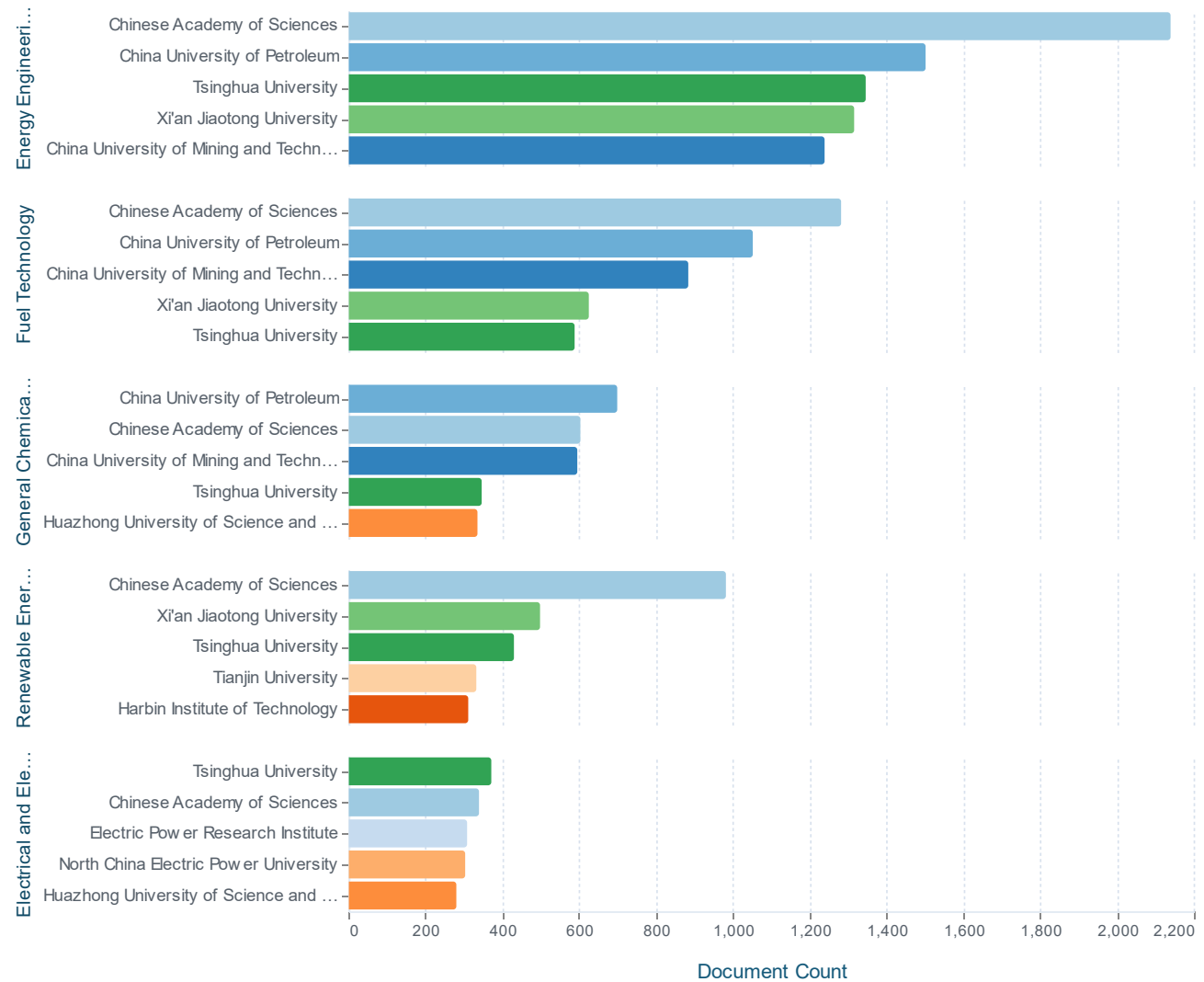

Fig. 5. The top Subjects for the most active institutions, based on their number of scholarly works 
In this article, we use Subject "Energy Engineering and Power Technology" as a filter, thus other Subjects can be viewed as intersections with it.

It is worth noting that Chinese publications usually have many co-authors. For example, in 23,033 Chinese articles on the topic "Energy Engineering and Power Technology" without US, UK and Australian co-authors, the average number of co-authors was 5.7, with average citation $6.2 .75 \%$ of articles have been cited. 26 publications were cited 100 times or more.

In 7,836 US articles on the topic "Energy Engineering and Power Technology" without Chinese co-authors affiliated with China, the average number of co-authors was 3.36 with average citation 5.5 and many of the co-authors have Chinese last names. $73 \%$ of articles have been cited. 26 publications were cited 73 times or more.

The average number of references per article for Chinese publications is 35.7 , and for US publications it is 32.5.

In short, the total number matters.

Top additional Subjects by articles of all institutions: Fuel Technology $\rightarrow 14,807$; Renewable Energy, Sustainability and the Environment $\rightarrow 11,082$; General Chemical Engineering $\rightarrow 7,041$; Electrical and Electronic Engineering $\rightarrow$ 5,858; Condensed Matter Physics $\rightarrow 3,838$; Nuclear Energy and $\quad$ Engineering $\rightarrow 3,787$; Organic Chemistry $\rightarrow 2,966$; Industrial and Manufacturing Engineering $\rightarrow 2,959$; Physical and Theoretical Chemistry $\rightarrow 1,971$; General Chemistry $\rightarrow 1,315$.

\subsection{Top Institutions with most published articles supported by Chinese Funding Organizations}

National Natural Science Foundation of China is the main fund for China $\mathrm{R} \& \mathrm{D}$, top institutions which get support from it are: Chinese Academy of Sciences (published 1,377 articles with NNSFC support), Xi'an Jiaotong University $\rightarrow 823$, Tsinghua University $\rightarrow 786$, China University of Petroleum $\rightarrow 759$, Huazhong University of Science and Technology $\rightarrow 693$ published articles.

Fundamental Research Funds for the Central Universities funding was given to: China University of Mining and Technology $\rightarrow 196$; China University of Petroleum $\rightarrow 189$; North China Electric Power University $\rightarrow 179$; Chongqing University $\rightarrow 125$; $X i$ 'an Jiaotong University $\rightarrow 120$ published articles.

National Basic Research Program of China (973 Program) funding was given to: Chinese Academy of Sciences $\rightarrow 175$; Tsinghua University $\rightarrow 106$; Xi' an Jiaotong University $\rightarrow 98$; Huazhong University of Science and Technology $\rightarrow 75$; China University of Petroleum $\rightarrow 59$ published articles.

China Postdoctoral Science Foundation: $X i$ 'an Jiaotong University $\rightarrow 150$; China University of Mining and Technology $\rightarrow 79$; Huazhong University of Science and Technology $\rightarrow 74$; Harbin Institute of Technology $\rightarrow 73$; Chinese Academy of Sciences $\rightarrow 68$ articles were published; National Key $R \& D$ Program of China: Chinese Academy of $\quad$ Sciences $\rightarrow 109$; $\quad \mathrm{Xi}$ 'an Jiaotong University $\rightarrow 52$; Huazhong University of Science and Technology $\rightarrow 50$; University of Science and Technology of China $\rightarrow 41$; Tsinghua University $\rightarrow 36$ published articles.

The diversity of donors ensures the sustainable development of Chinese science. 


\subsection{Top 5 journals with the most articles published by China's institutions}

Fig. 6 shows in which leading scientific journals which China's organizations with the largest number of publications on the subject "Energy
Engineering and Power Technology" place their articles.

These are classic top-rated energy journals, and the topics of publications are of great current interest as follows from the above text.

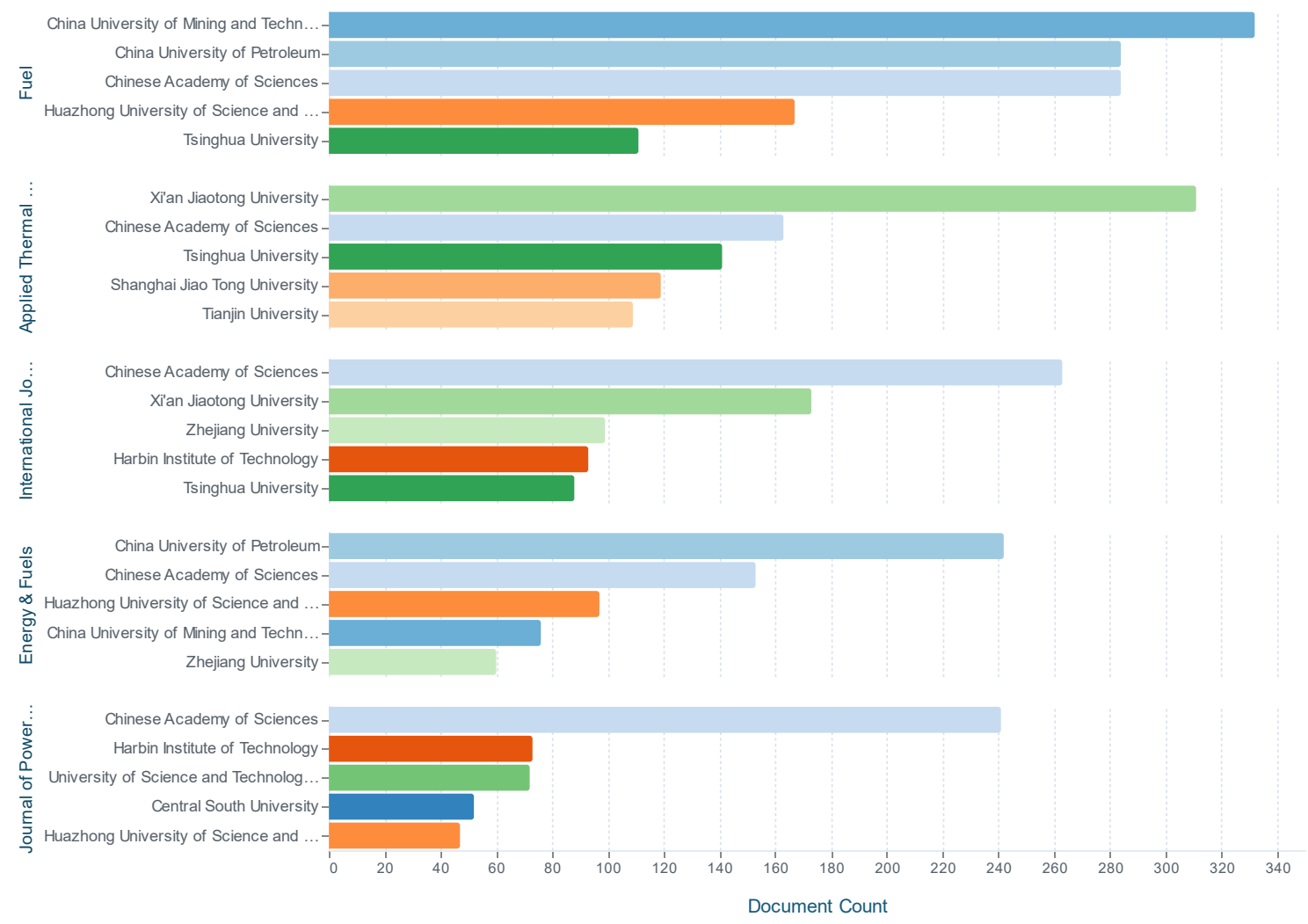

Fig. 6. The most active institutions by their number of scholarly works in the 5 top journals

\subsection{Constructing the Cluster Map of Fields of Study using VOSviewer}

VOSviewer constructs bibliometric maps based on a similarity matrix, which is calculated on the basis of co-occurrence matrix. It uses a similarity measure known as the association strength between two items calculated as the ratio between observed number of cooccurrences of items and the expected number of co-occurrences of items, under the assumption that occurrences of items are statistically independent [7]. The map can be divided into communities by cluster algorithm as a network in which nodes are densely connected internally within clusters, but loosely connected externally between different clusters. Each node in the map (network) is assigned to exactly one cluster. The number of clusters can be controlled by setting the minimum number of nodes in a cluster.

In this article, 16,233 Fields of Study as co-occurrence terms were used, 2,722 of them meet more than 10 times. The threshold of 10 items in cluster was used to construct the cluster map. As a result of the analysis, we obtained 5 clusters (Fig. 7), which are described in detail below. Format of data: Field of Study in lowercase (Links; Occurrence). 


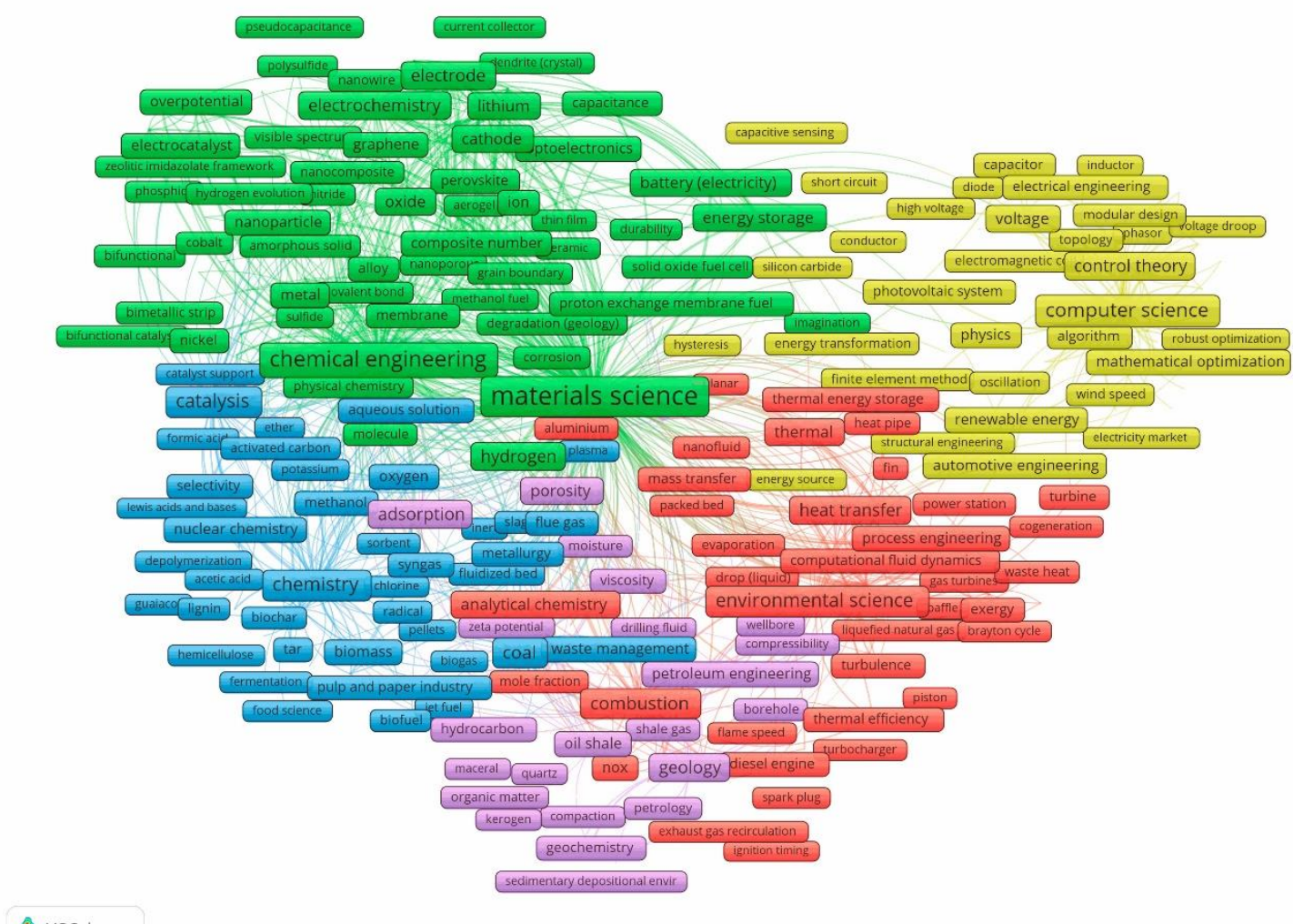

A vosviewer

Fig. 7.5 clusters of Fields of Study by their co-occurrence in metadata of publications

An enlarged graphical representation of the 5 clusters of the Fields of Study cooccurrence with details for each cluster is given in the Appendix (Fig. A.1, A.4-A.8). Fig. A.2 shows the change over time of the emergence of the Fields of Study. On Fig. A.3, a fragment of terms emerging over time for the cluster "Material science and chemical technology" is represented.

Cluster 1 (Red) - we could name it "Thermal efficiency and environmental science": environmental science $(724 ; 2678)$; mechanics $(619 ; 2549)$; combustion $(653 ; 1814)$; heat transfer (588;1157); flow (psychology) (611;973); thermal $(660 ; 940)$; analytical chemistry $(613 ; 846)$; nuclear engineering (474;778); thermodynamics $(573 ; 693)$; process engineering (455;676); ignition system $(375 ; 521)$; heat exchanger $(388 ; 436)$; $\mathrm{NO}_{\mathrm{x}} \quad(335 ; 419)$; diesel fuel $(388 ; 418)$; computer simulation (483;395); thermal efficiency (352;370); volumetric flow rate (490;361); supercritical fluid (448;334); combustor (333;326); thermal conductivity (396;317).

Cluster 2 (Green) - we could name it "Materials science for energy storage and hydrogen production by electrochemistry": materials science $(962 ; 14193)$; chemical engineering (778;6805); electrochemistry (470;1571); hydrogen (740;1373); anode (491;1303); carbon (645;1285); electrolyte (466;1202); electrode $(459 ; 1150)$; cathode (472;1070); battery (electricity) (527;1062); lithium (420;989); energy storage $(541 ; 809)$; oxide $(514 ; 785)$; hydrogen production $(502 ; 711)$; nanoparticle $(452 ; 654)$; graphene (412;650); composite number (525;634); supercapacitor (350;628); electrocatalyst (277;574); optoelectronics $(355 ; 506)$. 
Cluster 3 (Blue) - we could name it "Catalysis and pyrolysis for better fossil fuels": chemistry $(683 ; 3122)$; catalysis $(613 ; 2726)$; coal $(643 ; 1630)$; pyrolysis $(555 ; 997)$; inorganic chemistry $(448 ; 739)$; oxygen $(541 ; 610)$; biomass $(422 ; 558)$; waste management $(404 ; 531)$; nuclear chemistry $(366 ; 488)$; char $(338 ; 431)$; methanol (421;406); metallurgy $(396 ; 403)$; pulp and paper industry (316;399); syngas $(407 ; 394)$; flue gas (408;387); sulfur (386;340); particle size (455;326); desorption (398;312); thermogravimetric analysis $(351 ; 310)$; activation energy (376;309).

Cluster 4 (Yellow) - we could name it "Computer science and control theory for renewable energy by optimization and automotive engineering": computer science (450;3397); control theory $(360 ; 1481)$; voltage (466;896); electric power system $(315 ; 851)$; automotive engineering (355;590); renewable energy (424;549); mathematical optimization $(185 ; 520)$; physics $(320 ; 485)$; wind power (256;455); photovoltaic system (357;378); electricity generation (426;349); grid (229;333); AC power $(183 ; 307)$; mathematics $(314 ; 281)$; electrical engineering (184;277); algorithm (232;272); electricity (260;272); China $(136 ; 270)$; capacitor $(240 ; 263)$; engineering $(313 ; 263)$.

Cluster 5 (Violaceous) - we could name it "Petroleum engineering for new fossil fuel resources and composite materials": composite material $(697 ; 1417)$; geology $(336 ; 1201)$; adsorption $(642 ; 1151)$; porosity $(628 ; 781)$; methane $(592 ; 761)$; petroleum engineering $(353 ; 583)$; oil shale $(348 ; 533)$; geochemistry $(134 ; 404)$; particle $(490 ; 395)$; coal mining $(313 ; 380)$; natural gas $(447 ; 379)$; permeability (electromagnetism) $\quad(279 ; 298) ; \quad$ mineralogy (278;296); hydrocarbon (391;289); viscosity $(421 ; 284)$; structural basin $(128 ; 278)$; coalbed methane $(221 ; 258)$; saturation (chemistry)
$(363 ; 215)$; dissolution $(345 ; 210)$; fossil fuel $(333 ; 197)$.

\section{Conclusions}

It has been shown that the Lens platform, which provides open access to big bibliometric data of scientific publications and classifies them by Subject and Field of Study, can be used to analyze the scientific research landscape on a adjusted topic, which is important for $R \& D$ economic decision making.

"Energy Engineering and Power Technology" subject is a key topic in the area of Energy and includes 560,318 research papers in the Lens database. From 2018 to 2020, 90,173 papers were published: 26,366 by China, 10,393 by the United States and 4,319 by India.

Chinese publications on "Energy and Energy Production Technology" are more than doubled in their number compared to the global average over the past 10 years.

Most of these papers were funded by the National Natural Science Foundation of China. The Chinese Academy of Sciences; China Petroleum University; Tsinghua University; Xi' an Jiaotong University and China University of Mining and Technology are leading institutions in this subject.

Chinese articles on the topic "Energy Engineering and Power Technology" have the average number of co-authors 5.7 with average citation $6.2 .75 \%$ articles have been cited.

China conducts its research not only with the leading economies: United States, the United Kingdom, Australia and Canada, but also with the developing countries: Pakistan, Iran, Saudi Arabia and Viet Nam.

Materials science, chemical engineering, computer science, chemistry, catalysis and environmental science are the leading areas of research. 
The topics of research include works related to high-performance energy storage for various applications - from portable electronics to electric cars, new types of batteries, development of hybrid materials for advanced energy storage technologies, synthesis of monodisperse ultrafine nanosheets for anodes, increasing lithium-ion conductivity through doping, exploitation of unconventional gas fields such as coalbed methane.
Analysis of overlapping Fields of Study identified 5 thematic clusters: 1 . Thermal efficiency and environmental science; 2 . Materials science for energy storage and hydrogen production; 3. Catalysis and pyrolysis for fossil fuel improvement; 4. Computer science and control theory for renewable energy sources; 5. Oil and gas engineering for new fossil fuel resources and composite materials.

China is making great efforts to achieve its dominance in $R \& D$.

Статья написана в рамках выполнения государственного задания (тема «Фундаментальный базис инновационных технологий нефтяной и газовой промышленности (фундаментальные, поисковые и прикладные исследования)», № АААA-А19-119013190038-2).

\section{References}

1. Leydesdorff L., Rafols I. A global map of science based on the ISI subject categories // Journal of the American Society for Information Science and Technology. 2009. Vol. 60, No. 2. P. 348-362. https://doi.org/10.1002/asi.20967

2. Zhou P., Leydesdorff $L$. The emergence of China as a leading nation in science // Research Policy. 2006. Vol. 35, No. 1. P. 83-104. https://doi.org/10.1016/j.respol.2005.08.006

3. Yue T., Yang L., Ahlgren P. et al. A comparison of citation disciplinary structure in science between the G7 countries and the BRICS countries // Journal of Data and Information Science. 2018. Vol. 3, No. 3. P. 14-30. https://doi.org/10.2478/jdis-2018-0012

4. Carley S. Porter A.L., Rafols I., Leydesdorff L. Visualization of disciplinary profiles: Enhanced science overlay maps // Journal of Data and Information Science. 2017. Vol. 2, No. 3. P. 68-111. https://doi.org/10.1515/jdis-2017-0015

5. $Н и$ H., Wang D., Deng S. Global Collaboration in Artificial Intelligence: Bibliometrics and Network Analysis from 1985 to 2019 // Journal of Data and Information Science. 2020. Vol. 5, No. 4. P. 86-115. https://doi.org/10.2478/jdis-2020-0027

6. Zou L., Wang L., Wu Y. et al. Trends analysis of graphene research and development // Journal of Data and Information Science. 2020. Vol. 3, No. 1. P. 82-100. https://doi.org/10.2478/jdis-2018-0005

7. van Eck N.J., Waltman L. Software survey: VOSviewer, a computer program for bibliometric mapping // Scientometrics. 2010. Vol. 84, No. 2. P. 523-538. https://doi.org/10.1007/s11192-009-0146-3

8. Lin Y., Qiu Z., Li D. et al. $\mathrm{NiS}_{2} @ \mathrm{CoS}_{2}$ nanocrystals encapsulated in N-doped carbon nanocubes for high performance lithium/sodium ion batteries // Energy Storage Materials. 2018. Vol. 11. P. 67-74. https://doi.org/10.1016/j.ensm.2017.06.001

9. Wang H., Wang M., Tang $Y$. A novel zinc-ion hybrid supercapacitor for long-life and low-cost energy storage applications // Energy Storage Materials. 2018. Vol. 13. P. 1-7. https://doi.org/ 10.1016/j.ensm.2017.12.022 
10. Zheng $X$., Zhu Z., Lin $X$. et al. A mini-review on metal recycling from spent lithium-ion batteries // Engineering. 2018. Vol. 4, No. 3. P. 361-370. https://doi.org/10.1016/j.eng.2018.05.018

11. Zhu H., Ju Y., Qi Y. et al. Impact of tectonism on pore type and pore structure evolution in organic-rich shale: Implications for gas storage and migration pathways in naturally deformed rocks // Fuel. 2018. Vol. 228. P. 272-289. https://doi.org/10.1016/j.fuel.2018.04.137

12. Sun F., Yao Y., Li G., Li X. Performance of geothermal energy extraction in a horizontal well by using $\mathrm{CO}_{2}$ as the working fluid // Energy Conversion and Management. 2018. Vol. 171. P. 1529-1539. https://doi.org/10.1016/j.enconman.2018.06.092

13. Sun F., Yao Y., Li G., Li X. Geothermal energy development by circulating $\mathrm{CO}_{2}$ in a U-shaped closed loop geothermal system // Energy Conversion and Management. 2018. Vol. 174. P. 971-982. https://doi.org/10.1016/j.enconman.2018.08.094

14. Feng X., Ouyang M., Liu X. et al. Thermal runaway mechanism of lithium-ion battery for electric vehicles: A review // Energy Storage Materials. 2018. Vol. 10. P. 246-267. https://doi.org/10.1016/j.ensm.2017.05.013

15. Zheng F., Kotobuki M., Song S. et al. Review on solid electrolytes for all-solid-state lithiumion batteries // Journal of Power Sources. 2018. Vol. 389. P. 198-213. https://doi.org/ 10.1016/j.jpowsour.2018.04.022

16. Wang J., Zhou S., Zhang Z., Yurchenko D. High-performance piezoelectric wind energy harvester with Y-shaped attachments // Energy Conversion and Management. 2019. Vol. 181. P. 645-652. https://doi.org/10.1016/j.enconman.2018.12.034

17. Zhou C.W., Li Y., Burke U. et al. An experimental and chemical kinetic modeling study of 1,3butadiene combustion: Ignition delay time and laminar flame speed measurements // Combustion and Flame. 2018. Vol. 197. P. 423-438. https://doi.org/10.1016/j.combustflame.2018.08.006

18. Dai S., Liu Z., Zhao B. et al. A high-performance supercapacitor electrode based on N-doped porous graphene // Journal of Power Sources. 2018. Vol. 387. P. 43-48. https://doi.org/ 10.1016/j.jpowsour.2018.03.055

19. Yao J., Li Y., Massé R.C. et al. Revitalized interest in vanadium pentoxide as cathode material for lithium-ion batteries and beyond // Energy Storage Materials. 2018. Vol. 11. P. 205-259. https://doi.org/10.1016/j.ensm.2017.10.014

20. Zhang D.M., Jia J.H., Yang C.C., Jiang, Q. et al. $\mathrm{Fe}_{7} \mathrm{Se}_{8}$ nanoparticles anchored on N-doped carbon nanofibers as high-rate anode for sodium-ion batteries // Energy Storage Materials.2020. Vol. 24. P. 439-449. https://doi.org/10.1016/j.ensm.2019.07.017

21. Shao P., Yi L., Chen $S$. et al. Metal-organic frameworks for electrochemical reduction of carbon dioxide: The role of metal centers // Journal of Energy Chemistry. 2020. Vol. 40. P. 156-170. https://doi.org/10.1016/j.jechem.2019.04.013

22. Wu D., Wang $C$., Wu $M$. et al. Porous bowl-shaped $\mathrm{VS}_{2}$ nanosheets/graphene composite for high-rate lithium-ion storage // Journal of Energy Chemistry. 2020. Vol. 43. P. 24-32. https://doi.org/ 10.1016/j.jechem.2019.08.003

23. Zhao L., Guanhua N., Lulu S. et al. Effect of ionic liquid treatment on pore structure and fractal characteristics of low rank coal // Fuel. 2020. Vol. 262. P. 116513. https://doi.org/ 10.1016/j.fuel.2019.116513 
24. Chen S., Xie D., Liu G. et al. Sulfide solid electrolytes for all-solid-state lithium batteries: Structure, conductivity, stability and application // Energy Storage Materials. 2018. Vol. 14. P. 58-74. https://doi.org/10.1016/j.ensm.2018.02.020

25. Qiu, R., Fei, R., Guo, J.-Z. et. al. Encapsulation of $\mathrm{Na}_{3}(\mathrm{VO})_{2}\left(\mathrm{PO}_{4}\right)_{2} \mathrm{~F}$ into carbon nanofiber as a superior cathode material for flexible sodium-ion capacitors with high-energy-density and low-selfdischarge // Journal of Power Sources. 2020. Vol. 466. P. 228249. https://doi.org/ 10.1016/j.jpowsour.2020.228249

26. Liu J., Lu Z., Effat M.B., Ciucci F. Theoretical study on the stability and ionic conductivity of the $\mathrm{Na}_{11} \mathrm{M}_{2} \mathrm{PS}_{12}(\mathrm{M}=\mathrm{Sn}, \mathrm{Ge})$ superionic conductors // Journal of Power Sources. 2019. Vol. 409. P. 94-101. https://doi.org/10.1016/j.jpowsour.2018.10.077

27. Xu X., Li Y., Cheng J. et al. Composite solid electrolyte of $\mathrm{Na}_{3} \mathrm{PS}_{4}-\mathrm{PEO}$ for all-solid-state $\mathrm{SnS}_{2} / \mathrm{Na}$ batteries with excellent interfacial compatibility between electrolyte and Na metal // Journal of Energy Chemistry. 2020. Vol. 41. P. 73-78. https://doi.org/10.1016/j.jechem.2019.05.003 


\section{APPENDIX}

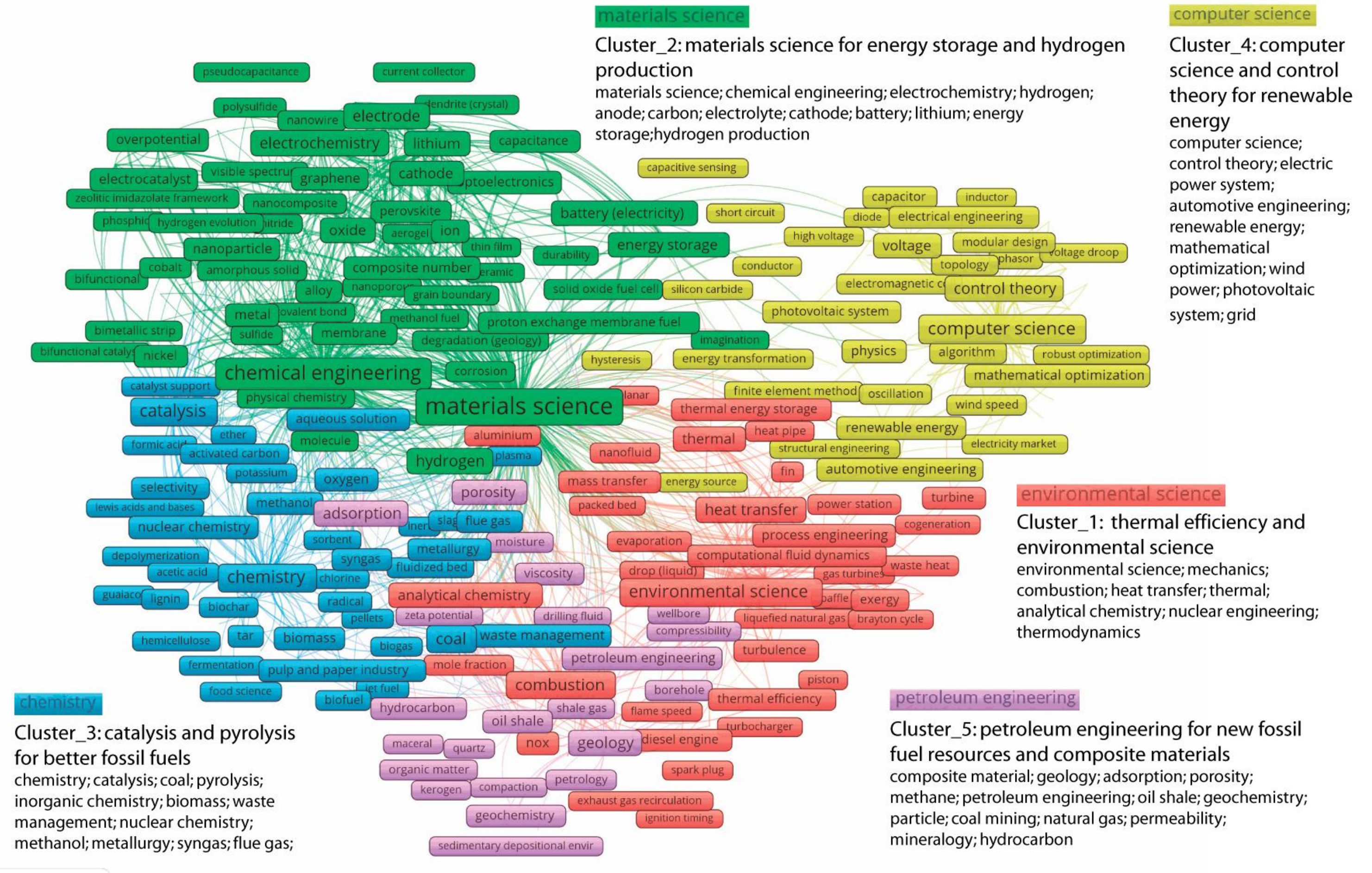

禹 vosviewer

Fig. A.1. Clustering the Fields of Study of China's scientific publications in 2018-2020 on the Subject "Energy Engineering and Power Technology" at the Lens platform 


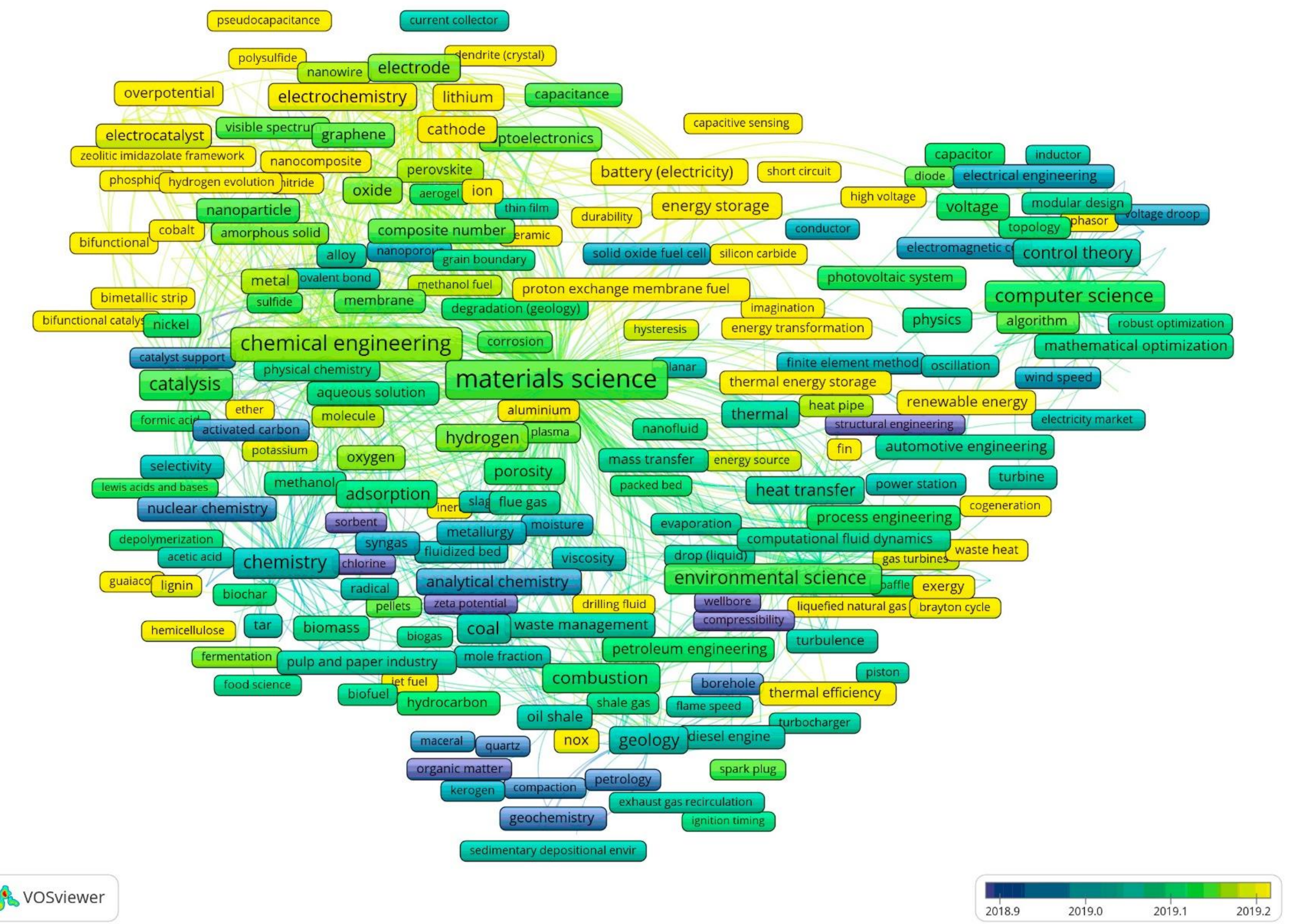

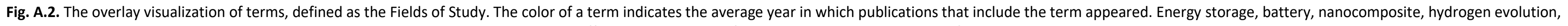
thermal efficiency, energy transformation are the hottest topics of publications 


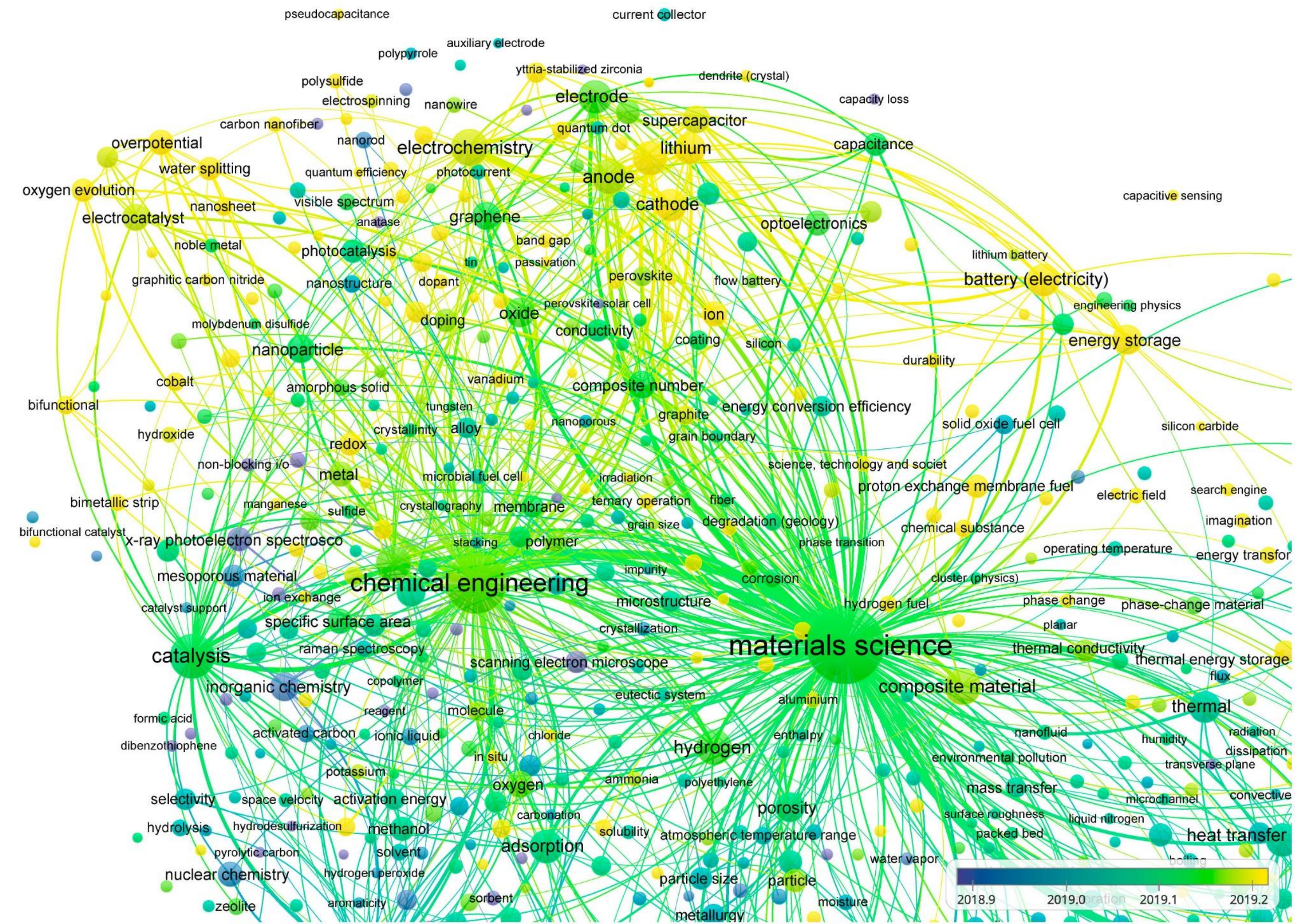

Fig. A.3. Fragment of semantic map for "Materials science and chemical engineering" cluster as overlay visualization of the Fields of Study 


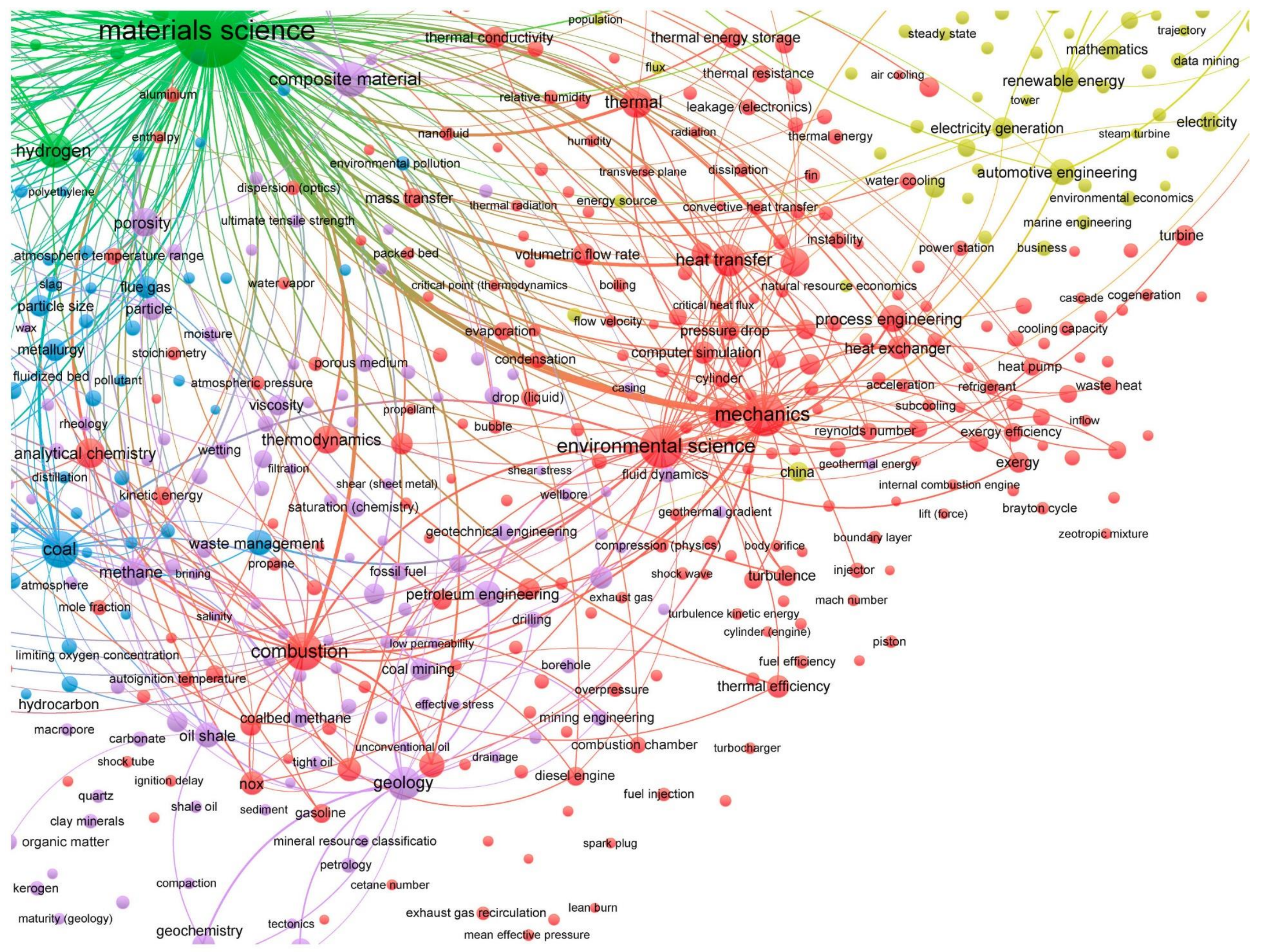

Fig. A.4. Cluster 1 (Red): Thermal efficiency and environmental science 


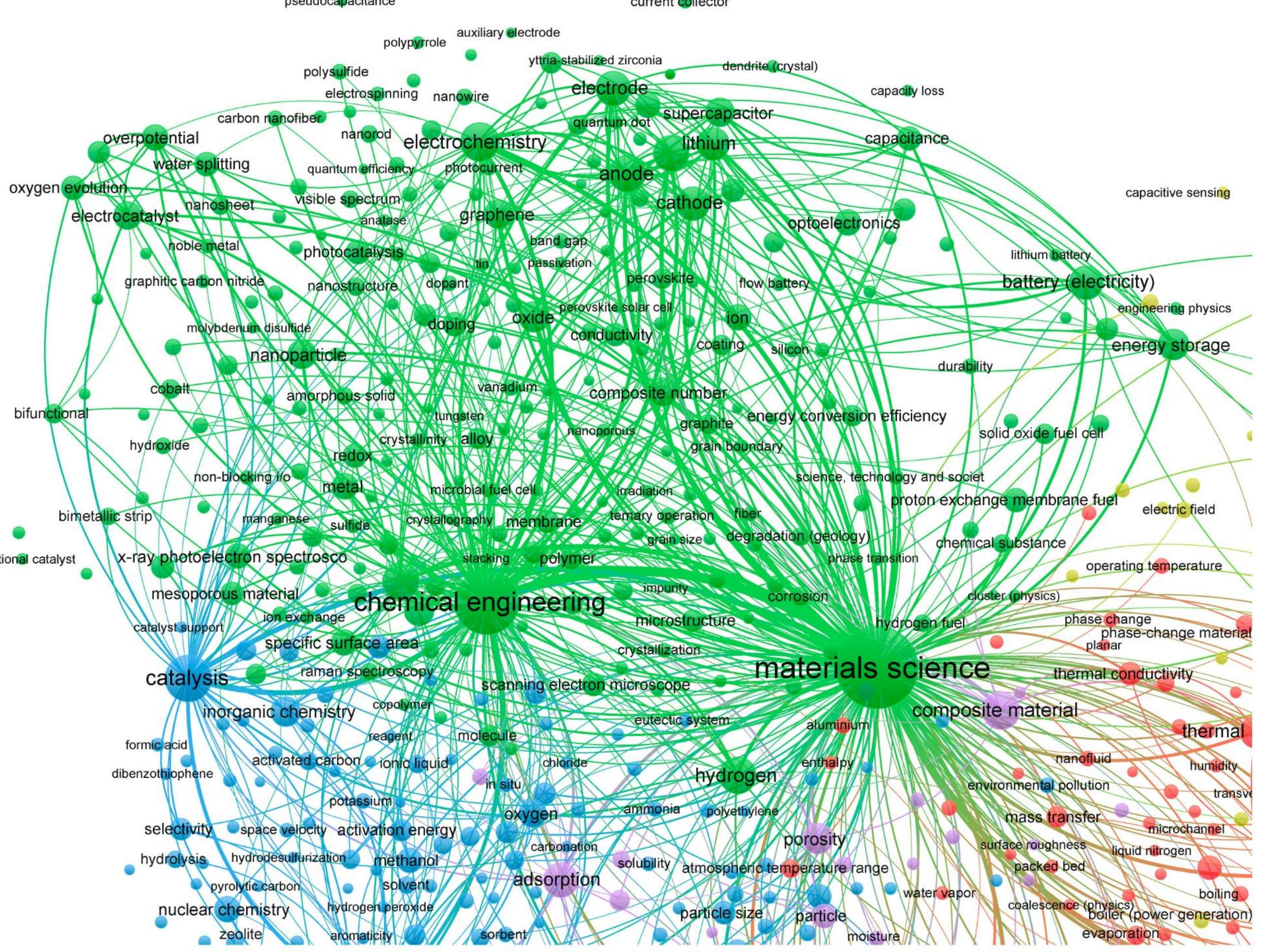

Fig. A.5. Cluster 2 (Green): Materials science for energy storage and hydrogen production by electrochemistry 


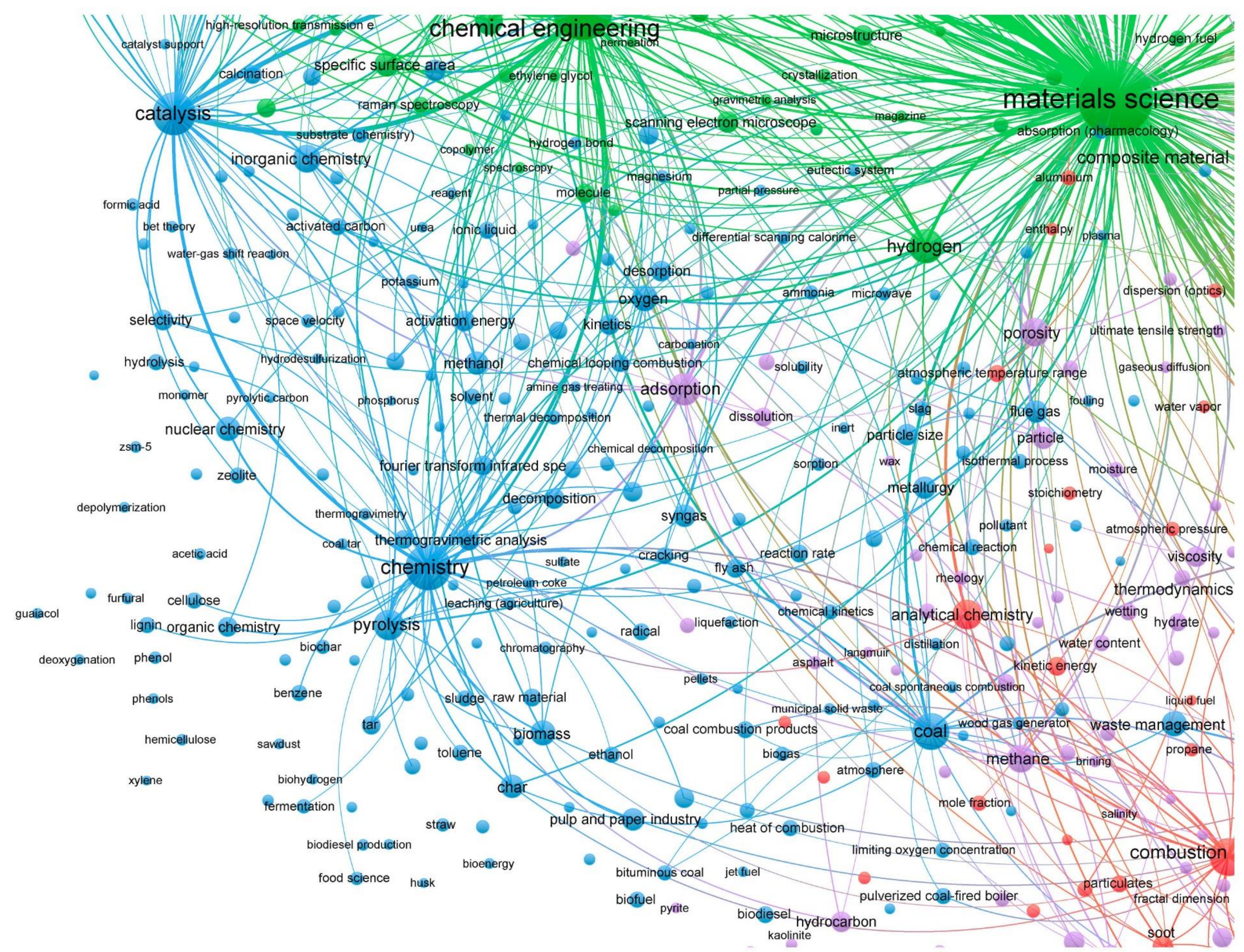

Fig. A.6. Cluster 3 (Blue): Catalysis and pyrolysis for better fossil fuels 


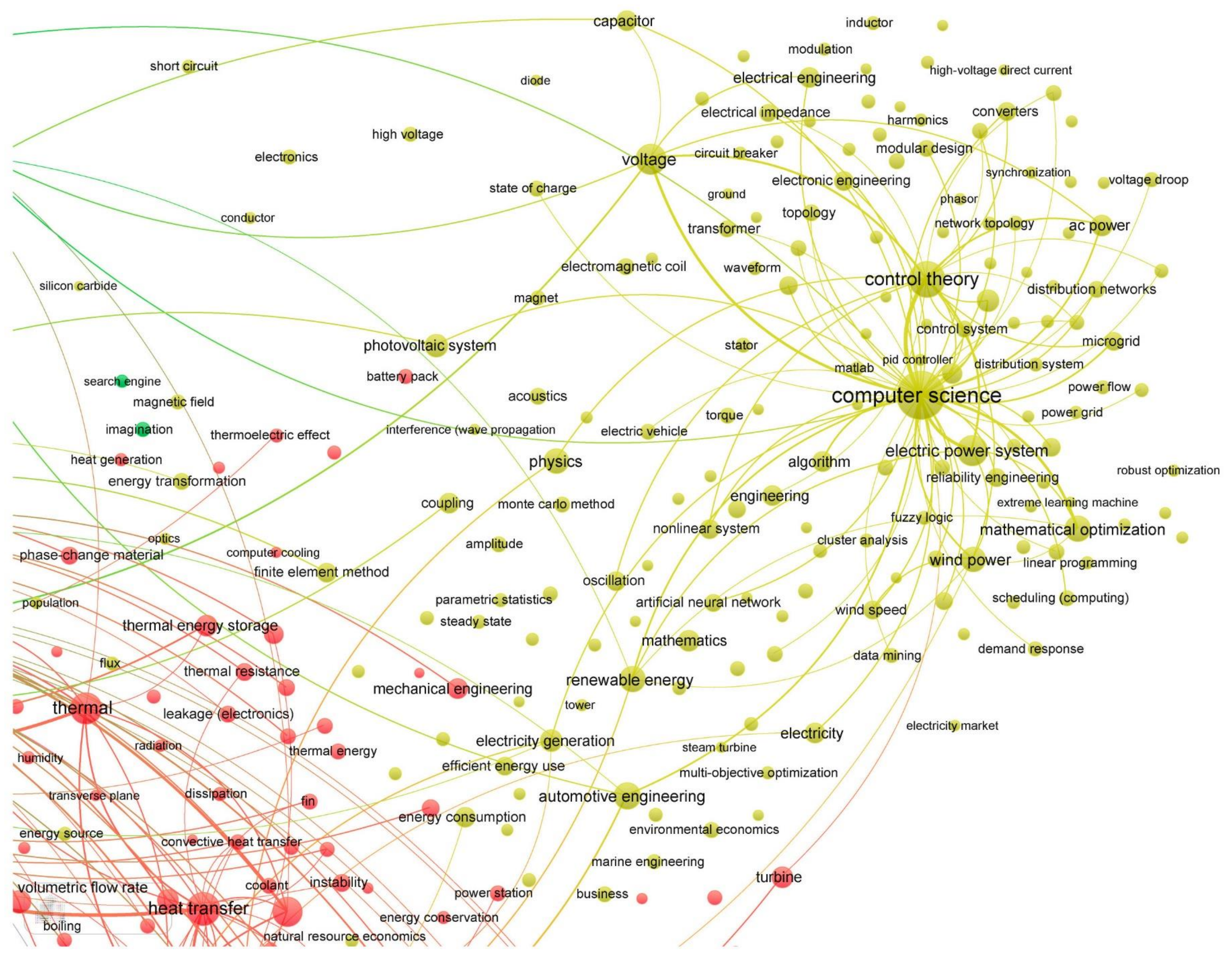

Fig. A.7. Cluster 4 (Yellow): Computer science and control theory for renewable energy by optimization and automotive engineering 

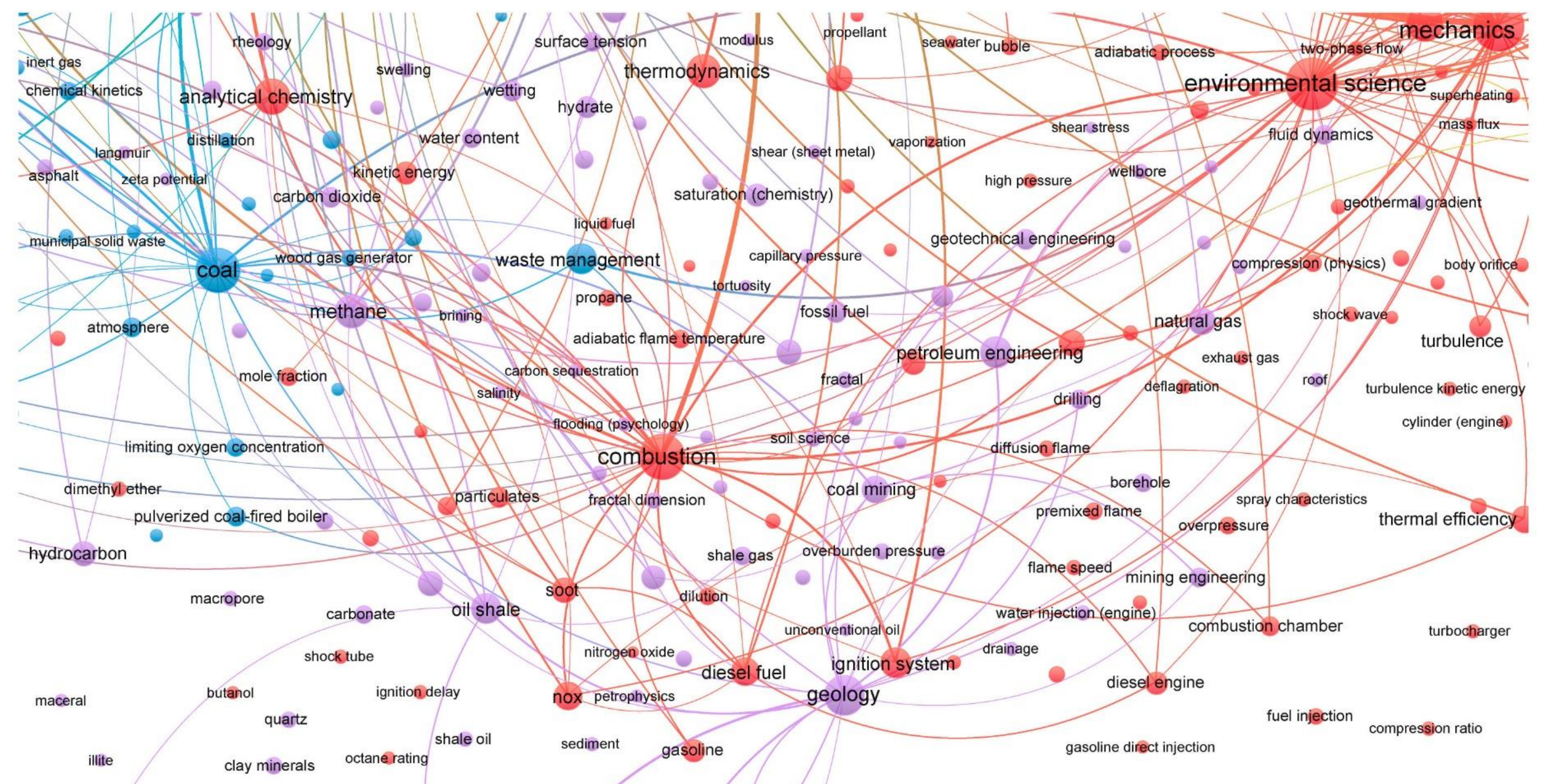

nox petrophysics geology 7

illite clay minerals octanerating shale oil sediment gasoline

gasoline direct injection

organic matter

dolomite
kerogen total organic carbon
maturity (geology)

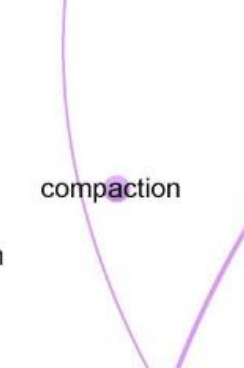

diagenesis geochemistry structural basin mineral/resource classificatio homogeneous charge compression sparkplug

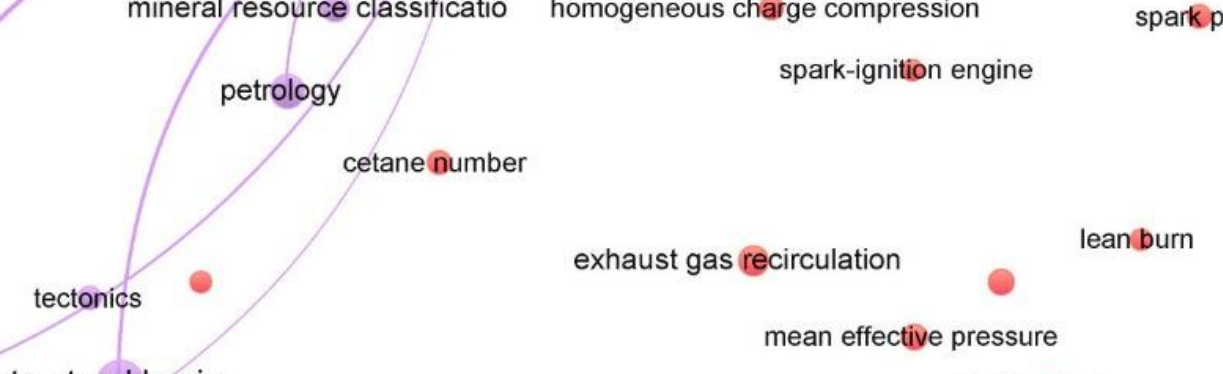

ource rock permian

sedimentary depositional envir

Fig. A.8. Cluster 5 (Violaceous): Petroleum engineering for new fossil fuel resources and composite materials 


\title{
Общее число имеет значение. Ландшафт китайских научных публикаций в 2018-2020 гг. по энергетической тематике
}

\author{
Б.Н. Чигарев \\ Институт проблем нефти и газа РАН, г. Москва \\ E-mail: bchigarev@ipng.ru
}

Аннотация. Целью данного исследования является анализ ландшафта научных публикаций Китая в 2018-2020 гг. на тему “Энергетическая инженерия и энергетические технологии» с использованием библиометрических данных платформы the Lens.

Использованы библиометрические данные 26623 научных работ, удовлетворяющих запросу: "фильтры: годы публикаций = (2018-); тип публикации = (статья в журнале); тема = (Энергетическая инженерия и энергетические технологии); страна = (Китай)», для анализа основных тем (поля базы данных: «Field of Study» и «Subject») и выявления ведущих участников данных научных исследований (поля Institution; Institution Country/Region; Funding; Journal).

Показано, что Китайская академия наук, Китайский нефтяной университет, Университет Цинхуа, Сианьский университет Цзяотун, Китайский университет горного дела и технологий ведущие учреждения в рассматриваемой области исследований. Большинство работ финансировалось Национальным фондом естественных наук Китая.

Китай проводит свои исследования не только совместно с ведущими экономиками: США, Великобританией, Австралией, Канадой, но и с развивающимися странами: Пакистаном, Ираном, Саудовской Аравией и Вьетнамом. Главные предметы научных работ: материаловедение, химическая инженерия, компьютерные науки, химия, катализ, экология.

Анализ совместной встречаемости значений поля «Field of Study» позволил выделить 5 тематических кластеров: 1. Тепловая эффективность и экология; 2. Материаловедение для систем накопления энергии и производства водорода; 3. Катализ и пиролиз для улучшения свойств углеводородного топлива; 4. Компьютерные науки и теория управления для оптимизации работы возобновляемых источников энергии; 5. Нефтяная инженерия для освоения новых ресурсов углеводородов и получения композиционных материалов.

Результаты работы могут служить справочным материалом для ученых, разработчиков и инвесторов для оценки направлений научных исследований в области «Энергетической инженерии и энергетических технологий».

Ключевые слова: Китай, энергетическая инженерия и энергетические технологии, ландшафт публикаций, библиометрия, реферативная база the Lens, область исследований.

Для цитирования: Чигарев Б.Н. Общее число имеет значение. Ландшафт китайских научных публикаций в 2018-2020 гг. по энергетической тематике // Актуальные проблемы нефти и газа. 2021. Вып. 1(32). С. 76-101. https://doi.org/10.29222/ipng.2078-5712.2021-32.art7

\section{Литература}

1. Leydesdorff L., Rafols I. A global map of science based on the ISI subject categories // Journal of the American Society for Information Science and Technology. 2009. Vol. 60, No. 2. P. 348-362. https://doi.org/10.1002/asi.20967

2. Zhou P., Leydesdorff $L$. The emergence of China as a leading nation in science // Research Policy. 2006. Vol. 35, No. 1. P. 83-104. https://doi.org/10.1016/j.respol.2005.08.006 
3. Yue T., Yang L., Ahlgren P. et al. A comparison of citation disciplinary structure in science between the G7 countries and the BRICS countries // Journal of Data and Information Science. 2018. Vol. 3, No. 3. P. 14-30. https://doi.org/10.2478/jdis-2018-0012

4. Carley S. Porter A. L., Rafols I., Leydesdorff L. Visualization of disciplinary profiles: Enhanced science overlay maps // Journal of Data and Information Science. 2017. Vol. 2, No. 3. P. 68-111. https://doi.org/10.1515/jdis-2017-0015

5. Hu H., Wang D., Deng S. Global Collaboration in Artificial Intelligence: Bibliometrics and network analysis from 1985 to 2019 // Journal of Data and Information Science. 2020. Vol. 5, No. 4. P. 86-115. https://doi.org/10.2478/jdis-2020-0027

6. Zou L., Wang L., Wu Y. et al. Trends analysis of graphene research and development // Journal of Data and Information Science. 2020. Vol. 3, No. 1. P. 82-100. https://doi.org/10.2478/jdis-2018-0005

7. van Eck N.J., Waltman L. Software survey: VOSviewer, a computer program for bibliometric mapping // Scientometrics. 2010. Vol. 84, No. 2. P. 523-538. https://doi.org/10.1007/s11192-009-0146-3

8. Lin Y., Qiu Z., Li D. et al. $\mathrm{NiS}_{2} @ \mathrm{CoS}_{2}$ nanocrystals encapsulated in N-doped carbon nanocubes for high performance lithium/sodium ion batteries // Energy Storage Materials. 2018. Vol. 11. P. 67-74. https://doi.org/10.1016/j.ensm.2017.06.001

9. Wang H., Wang M., Tang Y. A novel zinc-ion hybrid supercapacitor for long-life and low-cost energy storage applications // Energy Storage Materials. 2018. Vol. 13. P. 1-7. https://doi.org/ 10.1016/j.ensm.2017.12.022

10. Zheng $X$., Zhu Z., Lin $X$. et al. A mini-review on metal recycling from spent lithium-ion batteries // Engineering. 2018. Vol. 4, No. 3. P. 361-370. https://doi.org/10.1016/j.eng.2018.05.018

11. Zhu $H ., J u Y$., Qi Y. et al. Impact of tectonism on pore type and pore structure evolution in organic-rich shale: Implications for gas storage and migration pathways in naturally deformed rocks // Fuel. 2018. Vol. 228. P. 272-289. https://doi.org/10.1016/j.fuel.2018.04.137

12. Sun F., Yao Y., Li G., Li X. Performance of geothermal energy extraction in a horizontal well by using $\mathrm{CO}_{2}$ as the working fluid // Energy Conversion and Management. 2018. Vol. 171. P. 1529-1539. https://doi.org/10.1016/j.enconman.2018.06.092

13. Sun F., Yao Y., Li G., Li X. Geothermal energy development by circulating $\mathrm{CO}_{2}$ in a $\mathrm{U}$-shaped closed loop geothermal system // Energy Conversion and Management. 2018. Vol. 174. P. 971-982. https://doi.org/10.1016/j.enconman.2018.08.094

14. Feng X., Ouyang M., Liu X. et al. Thermal runaway mechanism of lithium-ion battery for electric vehicles: A review // Energy Storage Materials. 2018. Vol. 10. P. 246-267. https://doi.org/ 10.1016/j.ensm.2017.05.013

15. Zheng F., Kotobuki M., Song S. et al. Review on solid electrolytes for all-solid-state lithiumion batteries // Journal of Power Sources. 2018. Vol. 389. P. 198-213. https://doi.org/ 10.1016/j.jpowsour.2018.04.022

16. Wang J., Zhou S., Zhang Z., Yurchenko D. High-performance piezoelectric wind energy harvester with Y-shaped attachments // Energy Conversion and Management. 2019. Vol. 181. P. 645-652. https://doi.org/10.1016/j.enconman.2018.12.034

17. Zhou C.W., Li Y., Burke U. et al. An experimental and chemical kinetic modeling study of 1,3butadiene combustion: Ignition delay time and laminar flame speed measurements // Combustion and Flame. 2018. Vol. 197. P. 423-438. https://doi.org/10.1016/j.combustflame.2018.08.006 
18. Dai S., Liu Z., Zhao B. et al. A high-performance supercapacitor electrode based on N-doped porous graphene // Journal of Power Sources. 2018. Vol. 387. P. 43-48. https://doi.org/10.1016/ j.jpowsour.2018.03.055

19. Yao J., Li Y., Massé R.C. et al. Revitalized interest in vanadium pentoxide as cathode material for lithium-ion batteries and beyond // Energy Storage Materials. 2018. Vol. 11. P. 205-259. https://doi.org/10.1016/j.ensm.2017.10.014

20. Zhang D.M., Jia J.H., Yang C.C., Jiang, Q. et al. $\mathrm{Fe}_{7} \mathrm{Se}_{8}$ nanoparticles anchored on N-doped carbon nanofibers as high-rate anode for sodium-ion batteries // Energy Storage Materials.2020. Vol. 24. P. 439-449. https://doi.org/10.1016/j.ensm.2019.07.017

21. Shao P., Yi L., Chen S. et al. Metal-organic frameworks for electrochemical reduction of carbon dioxide: The role of metal centers // Journal of Energy Chemistry. 2020. Vol. 40. P. 156-170. https://doi.org/10.1016/j.jechem.2019.04.013

22. Wu D., Wang C., Wu $M$. et al. Porous bowl-shaped $\mathrm{VS}_{2}$ nanosheets/graphene composite for high-rate lithium-ion storage // Journal of Energy Chemistry. 2020. Vol. 43. P. 24-32. https://doi.org/ 10.1016/j.jechem.2019.08.003

23. Zhao L., Guanhua N., Lulu S. et al. Effect of ionic liquid treatment on pore structure and fractal characteristics of low rank coal // Fuel. 2020. Vol. 262. P. 116513. https://doi.org/ 10.1016/j.fuel.2019.116513

24. Chen S., Xie D., Liu G. et al. Sulfide solid electrolytes for all-solid-state lithium batteries: Structure, conductivity, stability and application // Energy Storage Materials. 2018. Vol. 14. P. 58-74. https://doi.org/10.1016/j.ensm.2018.02.020

25. Qiu, R., Fei, R., Guo, J.-Z. et. al. Encapsulation of $\mathrm{Na}_{3}(\mathrm{VO})_{2}\left(\mathrm{PO}_{4}\right)_{2} \mathrm{~F}$ into carbon nanofiber as a superior cathode material for flexible sodium-ion capacitors with high-energy-density and low-selfdischarge // Journal of Power Sources. 2020. Vol. 466. P. 228249. https://doi.org/ 10.1016/j.jpowsour.2020.228249

26. Liu J., Lu Z., Effat M.B., Ciucci F. Theoretical study on the stability and ionic conductivity of the $\mathrm{Na}_{11} \mathrm{M}_{2} \mathrm{PS}_{12}(\mathrm{M}=\mathrm{Sn}, \mathrm{Ge})$ superionic conductors // Journal of Power Sources. 2019. Vol. 409. P. 94-101. https://doi.org/10.1016/j.jpowsour.2018.10.077

27. Xu X., Li Y., Cheng $J$. et al. Composite solid electrolyte of $\mathrm{Na}_{3} \mathrm{PS}_{4}-\mathrm{PEO}$ for all-solid-state $\mathrm{SnS}_{2} / \mathrm{Na}$ batteries with excellent interfacial compatibility between electrolyte and Na metal // Journal of Energy Chemistry. 2020. Vol. 41. P. 73-78. https://doi.org/10.1016/j.jechem.2019.05.003 